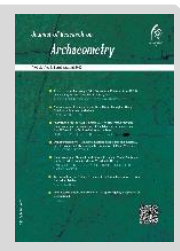

Original Paper

\title{
Analysis of Rock Cracks in Naqsh-e Rostam Historical Area by Remote Sensing
}

\author{
Azadeh Ghobadi $^{1 \star}$, Mohammad Amin Emami ${ }^{2}$, Hesam Aslani ${ }^{3}$, Behzad Ojaghi ${ }^{4}$ \\ ${ }^{1}$ Ph.D. candidate in Conservation of Cultural Heritage, Art University of Isfahan, Isfahan, IRAN \\ ${ }^{2}$ Associated prof. at Art University of Isfahan, Faculty of Conservation, Isfahan, IRAN \\ ${ }^{3}$ Assistant prof. at Art University of Isfahan, Faculty of Conservation, Isfahan, IRAN \\ ${ }^{4}$ RS/GIS expert, Project Manager at Yekom Consulting Engineers Institute, Tehran, IRAN
}

Received: $12 / 05 / 2018$

Accepted: 27/06/2019

\begin{abstract}
Cultural heritage sites are threatened from a variety of natural and anthropogenic factors. Innovative and cost effective tools are needed to protect them via systematic monitoring of landscapes and cultural heritage sites. In this study, the overall risk in the Naqsh-e Rostam area, as a case study, was assessed in a multidisciplinary approach, based on the remote sensing techniques and Geographical Information System (GIS) analysis. Naqsh-e-Rostam is known as an ancient periphery which is located in northwest of Persepolis in Fars (nowadays Shiraz), Iran. The oldest relief at Naqsh-eRostam is severely damaged and dates back to 1,200 B.C., while there is a rock relief thought to be Elamite, originally. Four tombs belonging to Achaemenid kings are carved out of the rock face and seven oversized rock reliefs at Naqsh-e-Rostam depict the monarchs of the Sassanid period. In Sasanian epoch, Naqsh-e-Rostam site was very important due to its religious and national role, where Ernst Emil Herzfeld and Heidemarie Koch estimated its ancientness about 4,000 B.C. This historical site, which is one of the most unique ancient monuments in Iran, is suffering from some problems such as erosion and deep cracks, due to mainly the climatic and geological characteristics of the region. Currently, several damages threaten this site, which are also remarkable on the high reliefs and on the ground, vicinity of the reliefs. These monuments are located in orographic mountains which expose overall to interaction with their surrounded environment. Therefore, existing deterioration as well as erosion process is mainly due to the climatic conditions and geo-environmental factors that cause such challenges. The aim of this study was to analyze the unexpected appearance of a deep fracture with unknown reasons in this site during the recent years and to find the basic phenomenon for the appearance and development of these fractures. First, several natural and anthropogenic hazards were mapped using different remote sensing data and methodologies. All data were gathered from satellite images and products. Then, the results from each hazard were imported into a GIS environment in order to examine the overall risk assessment based on the Analytic Hierarchy Process (AHP) methodology. The results showed that the methodology applied was effective enough in the understanding of the current conservation circumstances of the monuments in relation to their environment, as well as in the prediction of the future development of the present hazards. Transverse and main cracking are dominant damages that will result erosion in whole of these works. The focal pressure sources, which produced once drainage and haulage of water stream along the crack systems in the rock surfaces, was studied with Aerial Photography and Satellite Imagery, and analyzed with respect to GIS system. Finally, the gullies effect was identified in the back of the rocks. Keywords: Naqsh-e Rostam, Remote Sensing, Geographic Information System, Digital Elevation Model, Gullies
\end{abstract}

*Corresponding author: azadeh.ghobadi@yahoo.com 


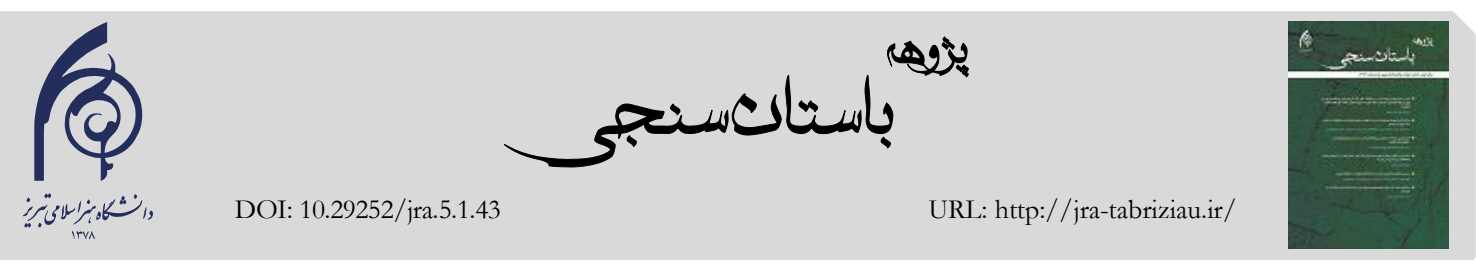

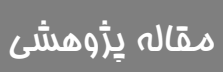

\section{(D)}

بر رسى تركهاى آثار صخرهاى محوطه تاريخى نقث رسته

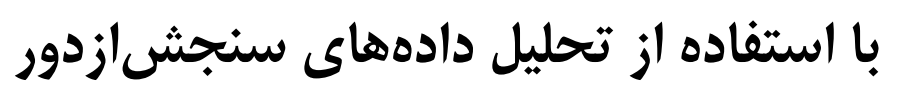

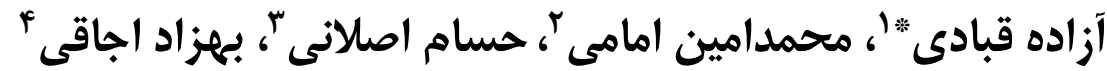

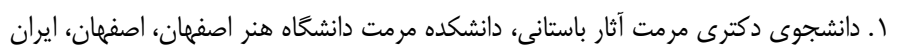

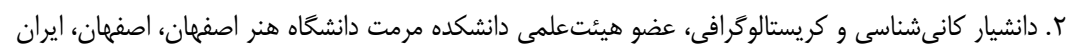

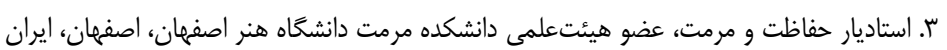

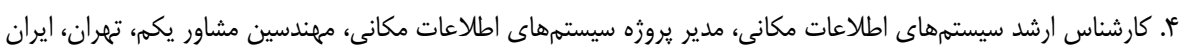

محوطه تاريخى نقش ر ستم يكى از آثار منح صربهفرد ايران واقع در ا ستان فارس ا ست كه يادمانهايى از عيلاميان، ههار

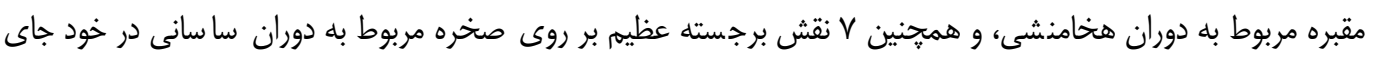

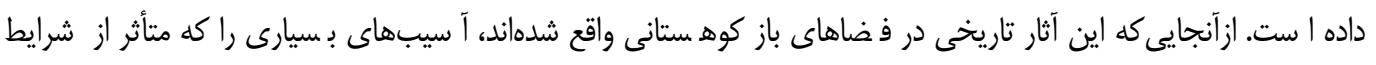

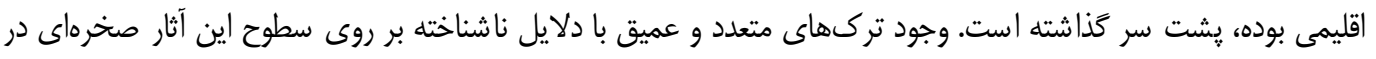

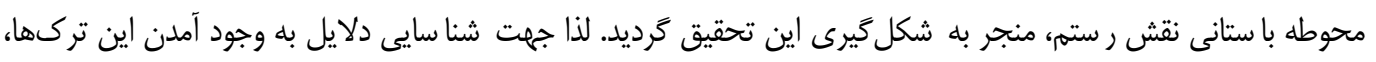

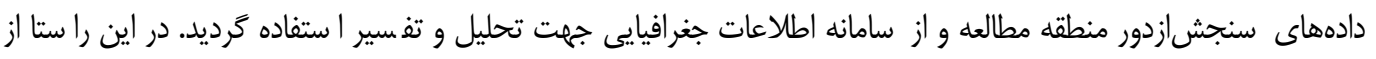

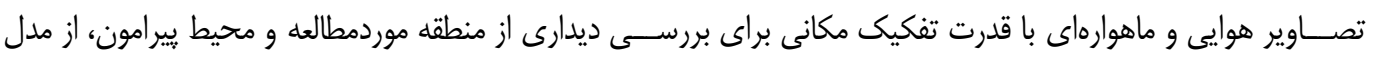

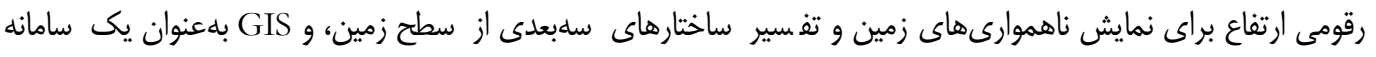

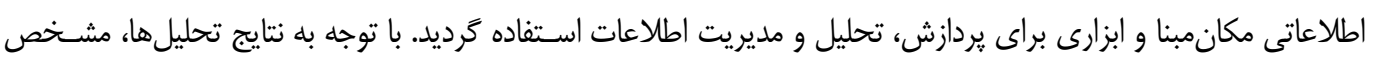

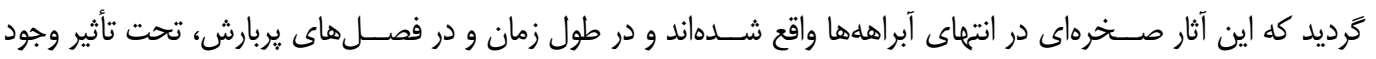

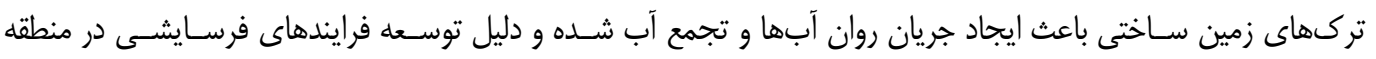

$$
\text { موردمطالعه هستند. }
$$

وازَّان كليدى: نقش رسته، سنجشازدور، سامانه اطلاعات جغرافيايى، مدل رقومى ارتفاع، روان آب 
حسـين كوه، [5]به علت اقليم و عوامل زمينشــاسـى آ سيبهاى فراوان جون فر سايش و تركهاى عميق دارد

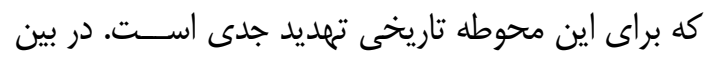

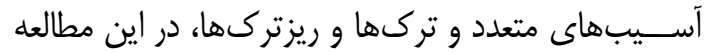
جهار ترك بر روى جهيار مقبره هخامنشـى كه از از بالاى

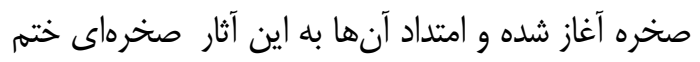

$$
\text { شده است بررسى شدند (شكل ()). }
$$

ارتفاعات منطقه مرود شت در قسمت مركزى ر ر شته

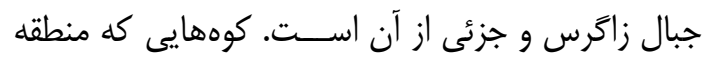

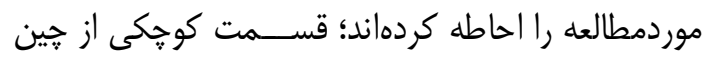

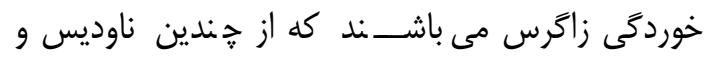
طاقديس تكتونيكى ز شكيل يافتهاند. آهكهاى بانس كرتا سه

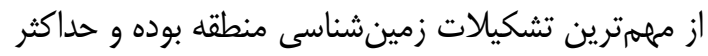

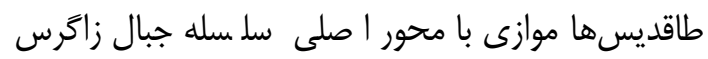
است. تشكيلات زمين شناسى منطقه از كامبرين (دوران

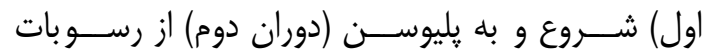

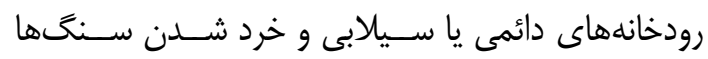

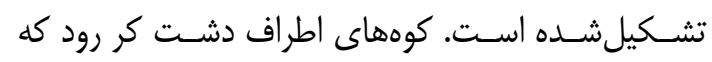

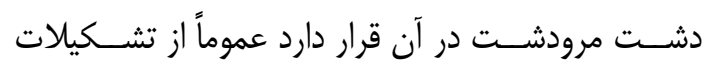
آهكى (آهكهاى مارنى ودولومى) تشـكيل يافته اسـت درونت

آهكها در محور طاقديسها خردشـــده و درزهايى ييدا كرداند و در بيشتر نقاط شكستخى ها و گسل هائى

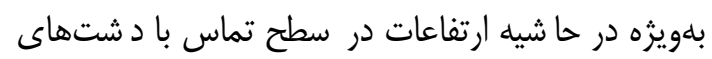

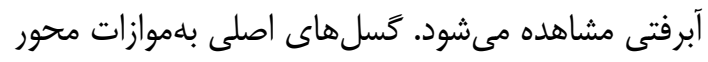

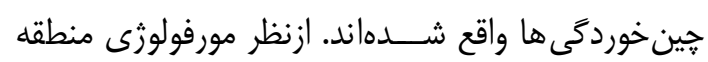
مرودشت جزئى از حوضه آبريز طشتك نى ندريز

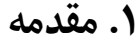

نقش رستم نام مجموعهاى باستانى در روستاى زنگگى آباد واقع در شمال شهر ستان مرود شت استان فارس ايران

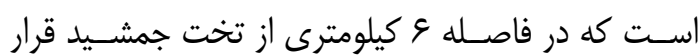
دارد. اين محوطه باسـتانى يادمان هايى از عيلاميان،

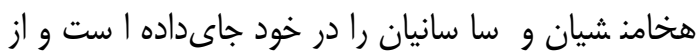

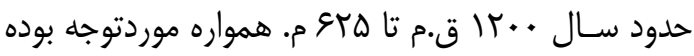

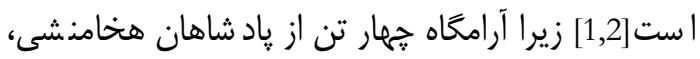
نقش برجســــهـــاى متعـددى از وقـايع مهم دوران

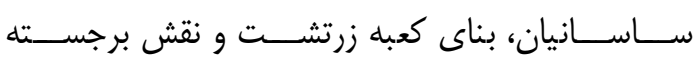
ويرانشـدهاى از دوران عيلاميان در اين مكان قرار دارند و در دوره سـاسـانى، محوطه نقش رسـتم ازنظر دينى و ملى نيز اهميت بسيار داشته است [3].

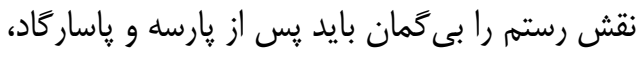

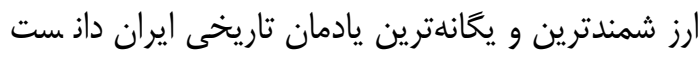
كه در دوره اسـلامى نيز ارزش خود را را حفظ كرده و و مورد

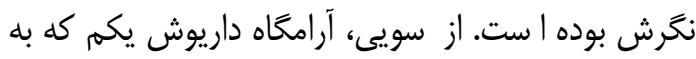

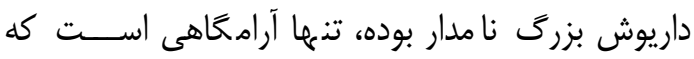

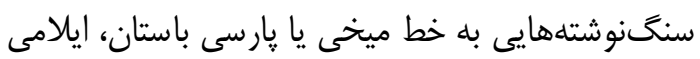

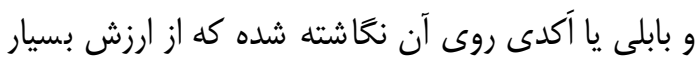

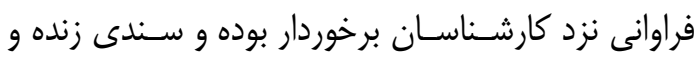

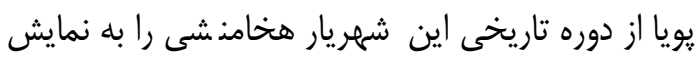

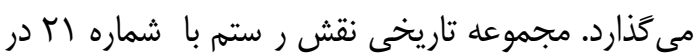

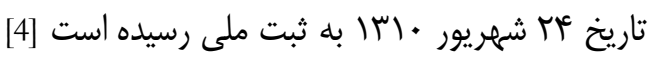

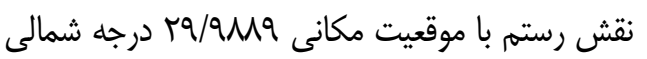

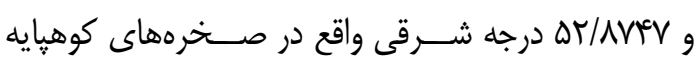

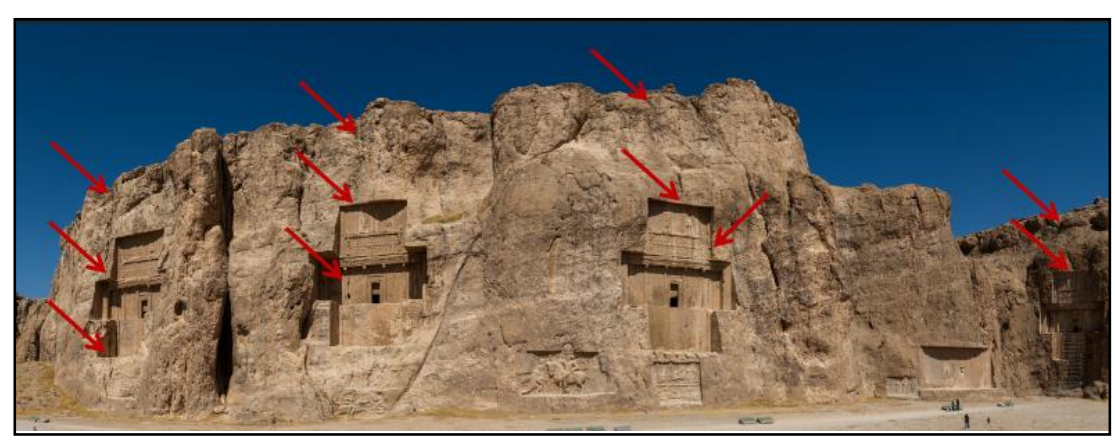

شكل ) تصوير پارانوما از آثار صخرهاى محوطه تاريخى نقش رستم و تركهاى موردمطالعه

Fig.1: Panorama of Naqsh-e Rostam Rock relief 
است كه اين آثار را تهديد مىنمايد و مبناى تشكيل آنها

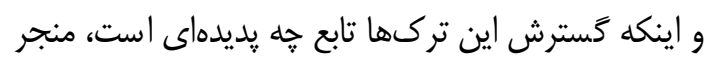
به شكل تيرى اين تحقيق گر ديد.

\section{r. بيشينه تحقيق}

حجارى روى سنگ نوعى از برج سته سازى است كه با ساخت بعد بر روى ديوارههاى عظيم صخرهها سعى در انتقال مفاهيم خاصسى داشـته كه اغلب مربوط بـ به دوران مخرهان تاريخى مشخصى است هنر صخرهاى، نمونهاى مشخص

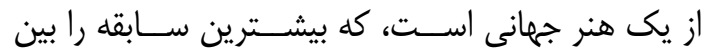

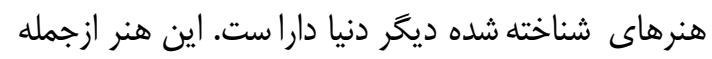

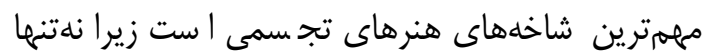
نخ ستين جلوههاى شناخته شده از > سا سيت هنرى و

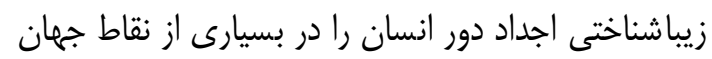
به نمايش مى كذارد، بلكه يكى از رايجترين شـــيوههاى

$$
\text { بيان ييامها و فرهنگ انسان است [9]. }
$$

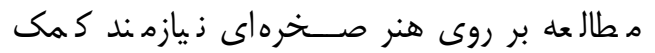
مجمو عهاى از علوم نوين و خاص اســـت. علومى نظير

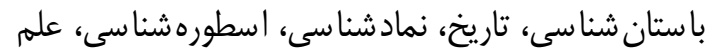

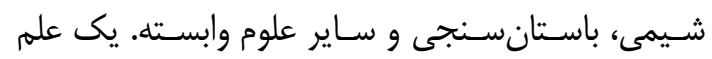
بلتنهايى قادر به مطالعه بر روى آنها نيست

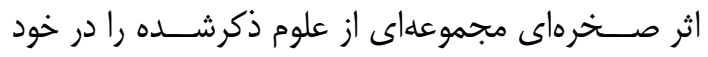

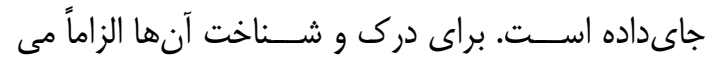
بايست از همه علوم مذكور و صاحبنظران آن

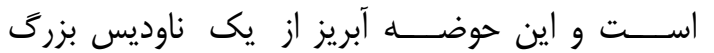

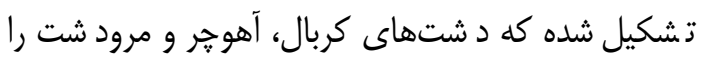

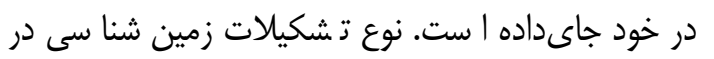

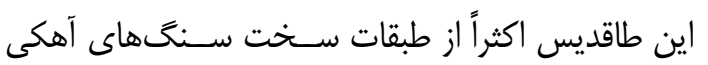

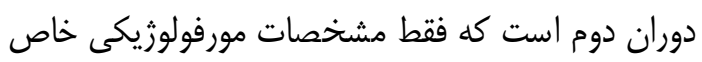

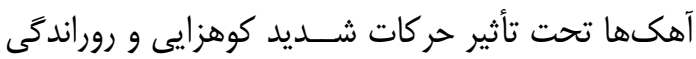

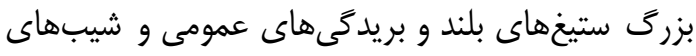

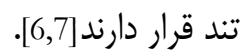

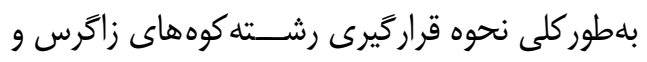

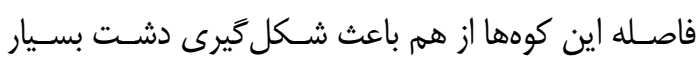

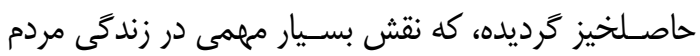

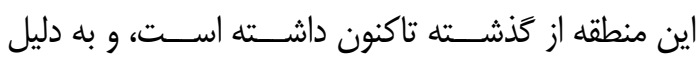
قراركيرى در موقعيت خاص تاريخى و جغرافيايى همواره

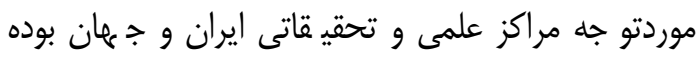

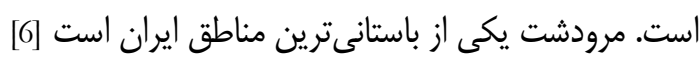

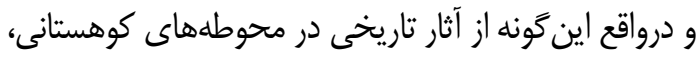
همواره در معرض تخر يب و فرســايش عوامل طبيعى و

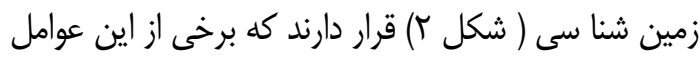

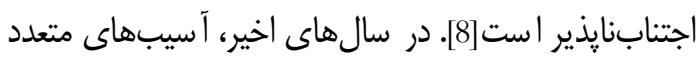

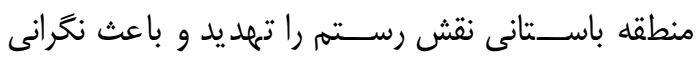

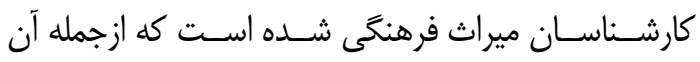

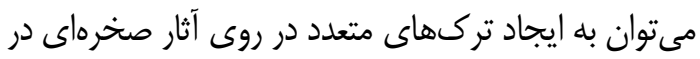

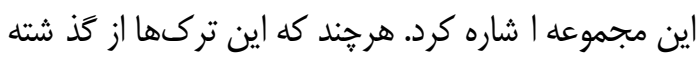

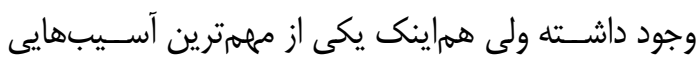

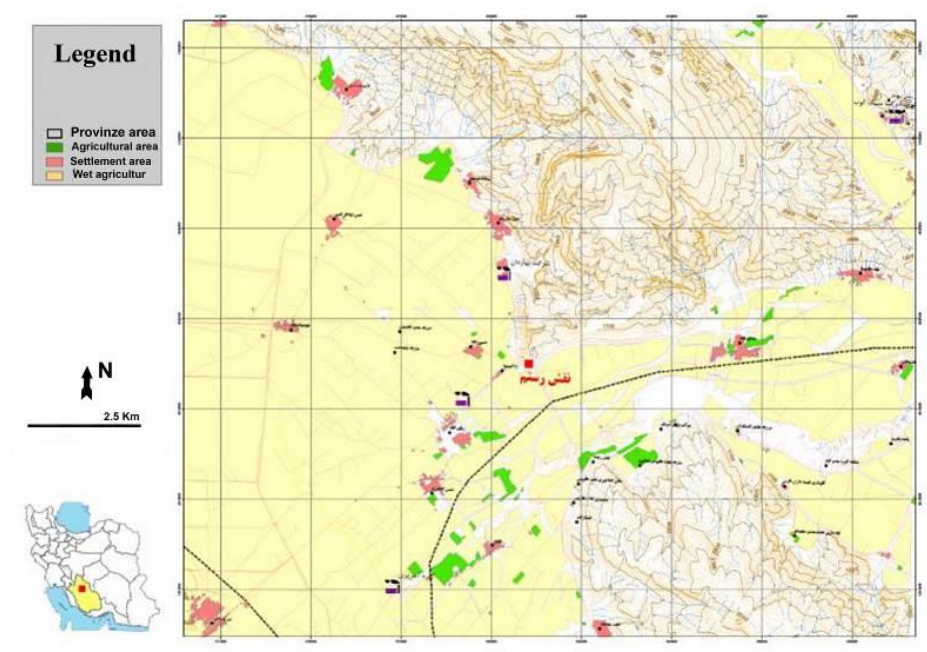

شكل r: نقشه موقعيت عمومى و تويوكرافى محوطه تاريخى نقش رستم

Fig. 2: Topography of Naqsh-e Rostam

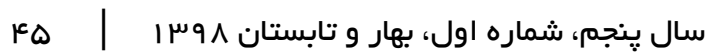


در اثر بارش باران و سيلاب اتفاق افتاده باشد.

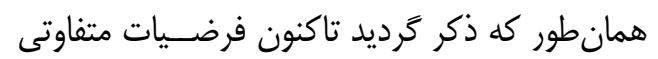

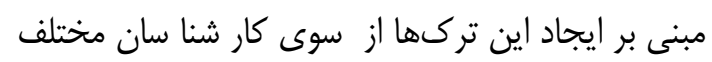

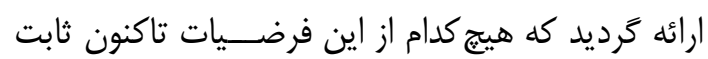

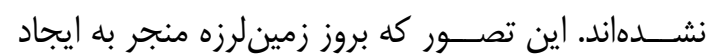

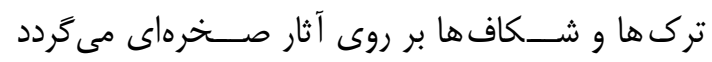

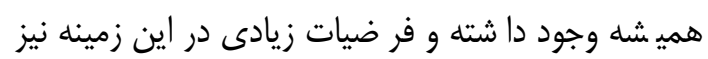

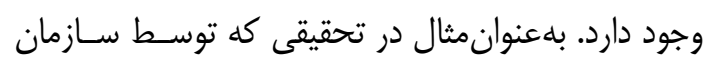

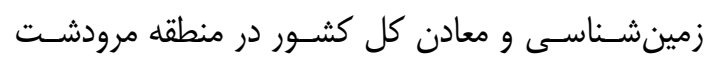

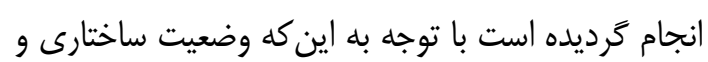
زمين شناسى كوه رحمت وضعيت زمين شناسى مهندسى إنى

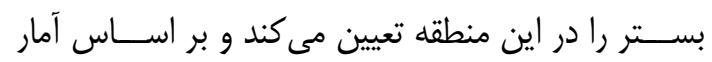

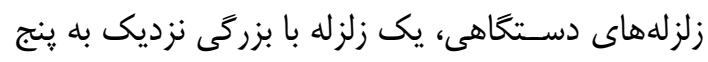

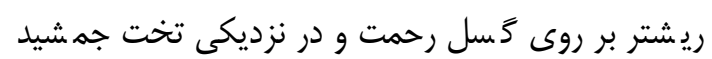

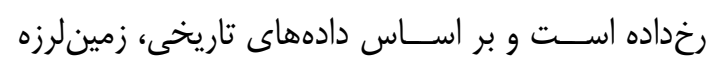

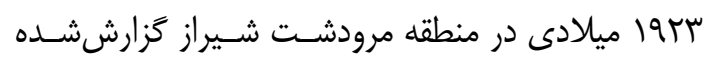

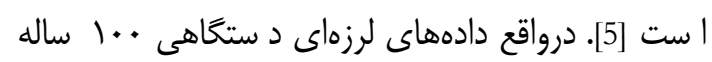

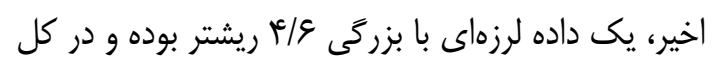

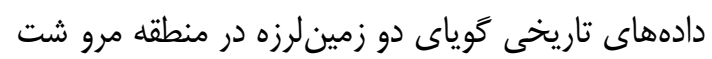

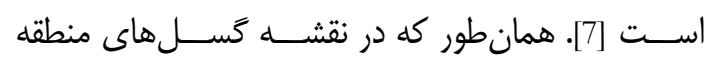
مرود شت مشخص شده است، فاصله نزديكترين كَّل

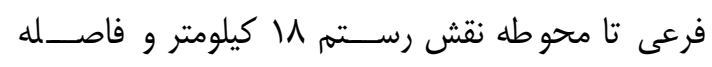

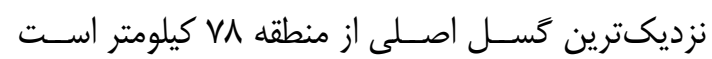

(شكل س).
رشــته ها بلهور ســيسـتمى كمك گر فت [9,10]. برجستهترين نقوش بعد دار در ايران كه برجسته سازى و و

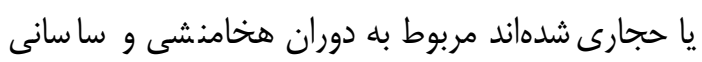

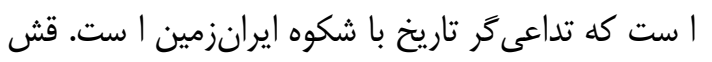

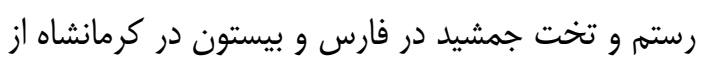

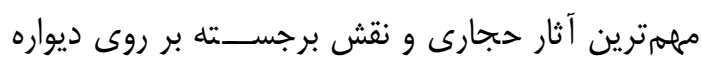
صخرهها مىباشند [9]، كه به علت قرار داشتن در فضاى نقاي باز دجار آ سيبهاى متعددى هـ ستند و معمولاً روشهاى لهاى

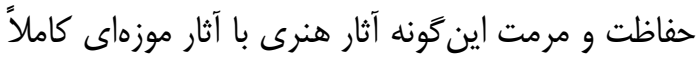
متفاوت است. كار شنا سان و يزوهشخَران در حوزه ميراث فرهنكى

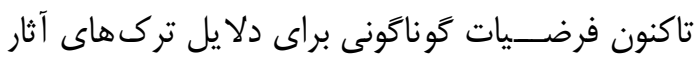

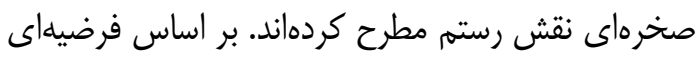

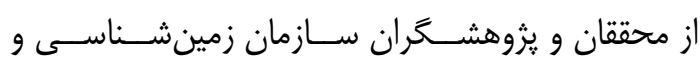

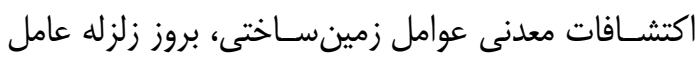

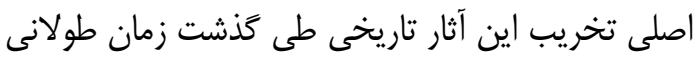

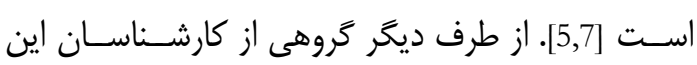

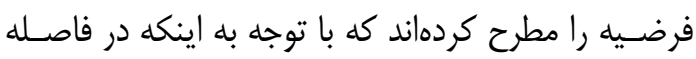

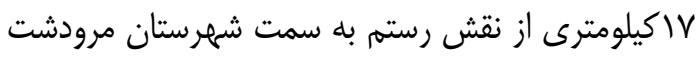

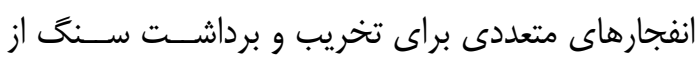

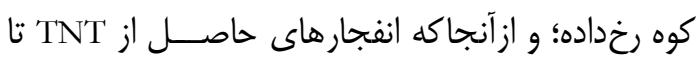

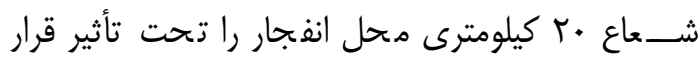

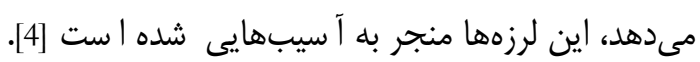

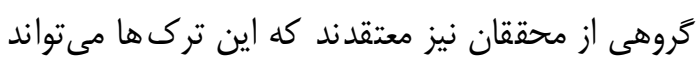

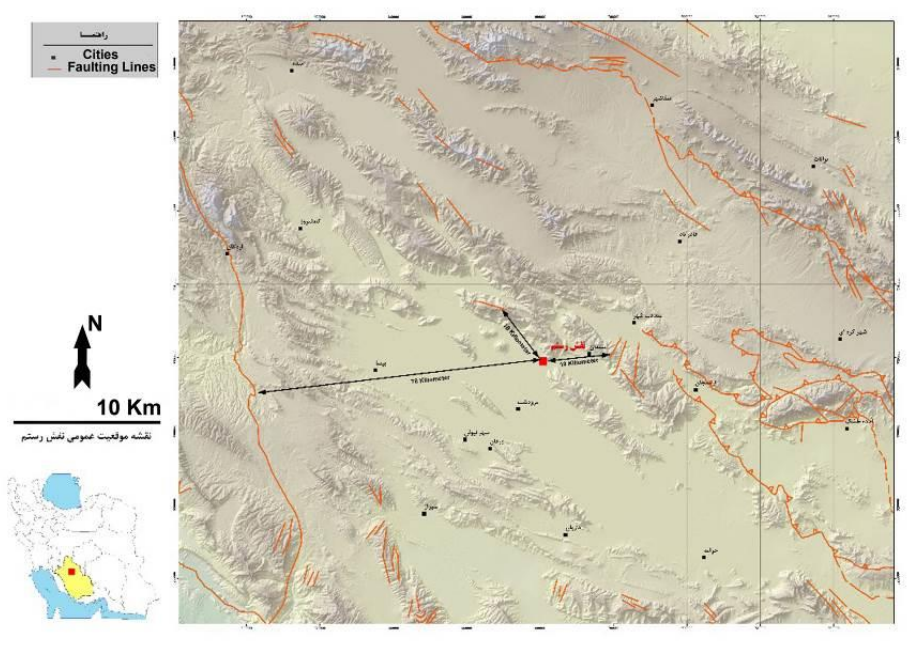

شكل س: نقشه گسل هاى منطقه مرودشت

Fig. 3: Map of Faults for Marvdasht 
يي شرفتى ندا شته ا ست ( شكل أ) و به همين ترتيب در

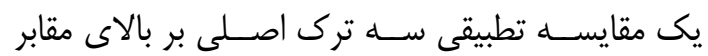

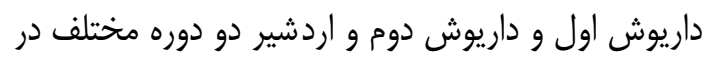

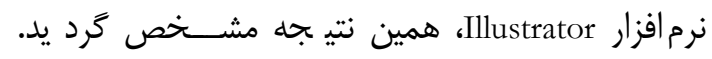

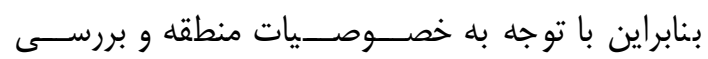

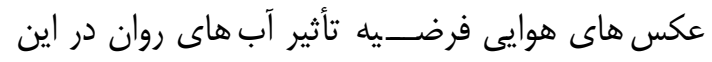
تحقيق موردبررسى و مطالعه قرار مى گيرد.

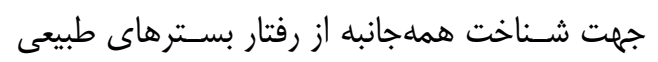
همجون منطقه نقش رستم، نياز به استفاده از
همجنين با بررســى عكس هاى موجود متعلق به

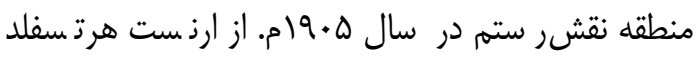

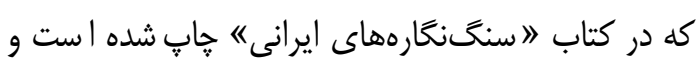

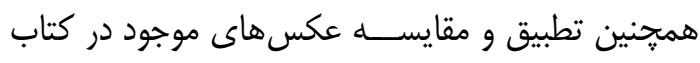

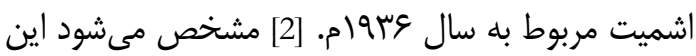
تركها درصد سال كذشته با زمين لرزههاى اخير به وجود نيامده اسـت در عكسها دو ترك موجود بر بالاى مقبره

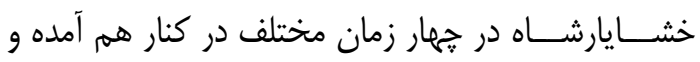

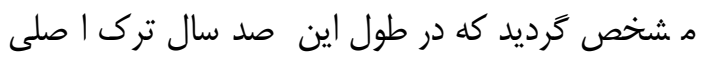

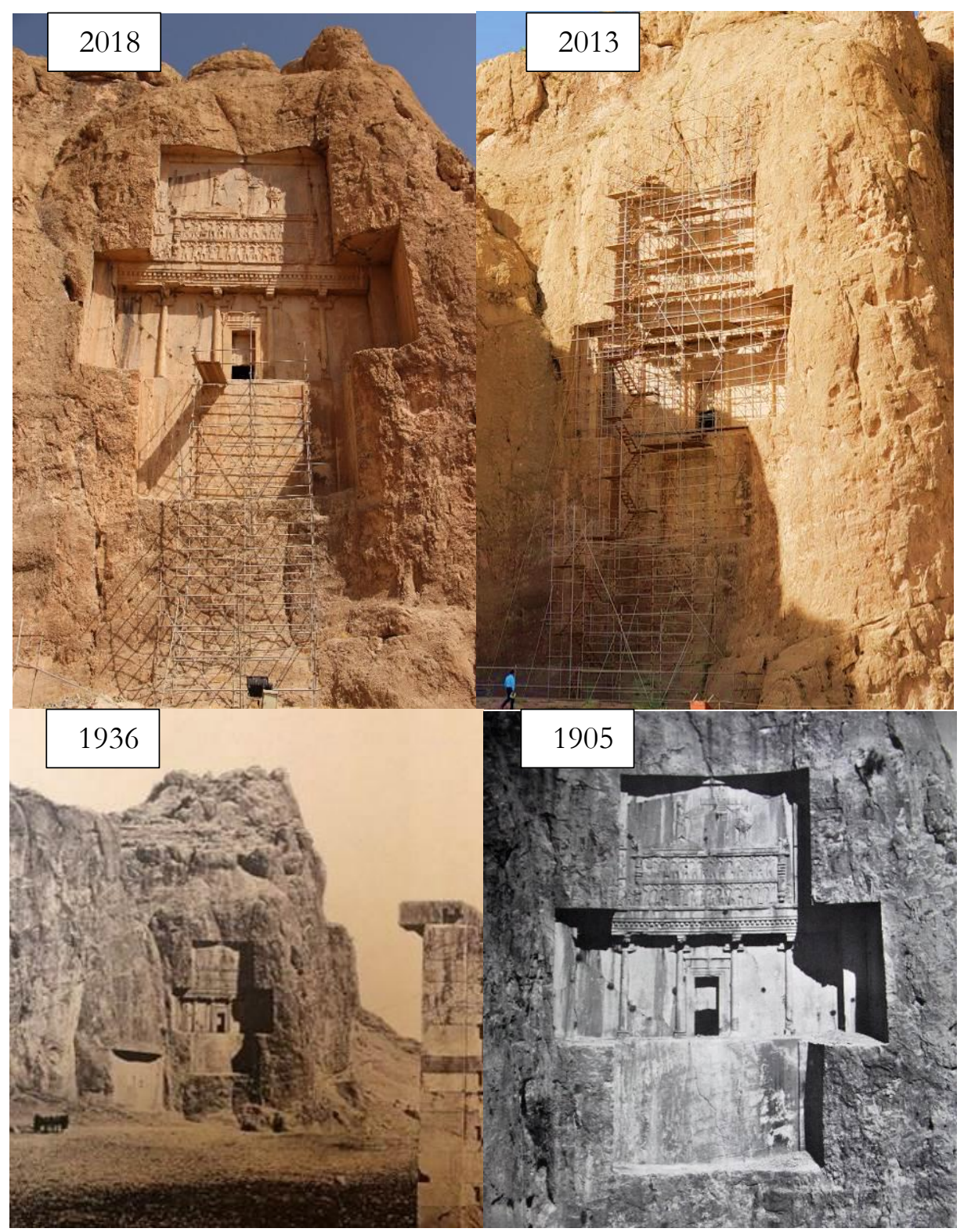

شكل عا: ترك عمودى بر بالاى مقبره خشايارشاه در صدسال اخير

Fig. 4: Track on rock surface of Xerxes Tomb in different ages

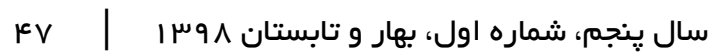


با اســتفاده از دادههاى ماهوارهاى مىتوان تهيه نقشـــهـ

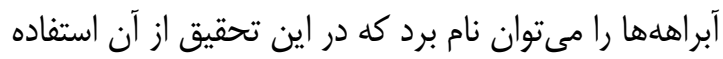
كرديد.

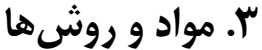

در اين يزوهش، محوطه تاريخى نقش رســتم با توجه به

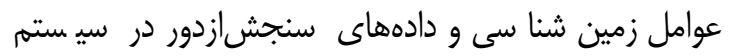

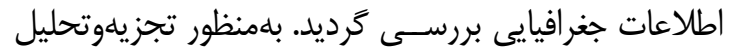

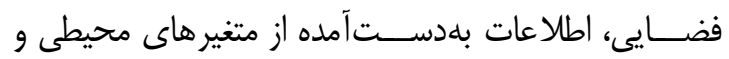

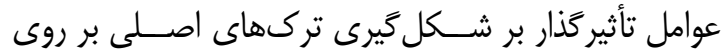

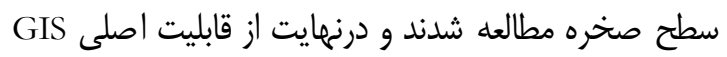
كه تحليل و يردازش دادههاى مكانى است، استفاده كرديد.

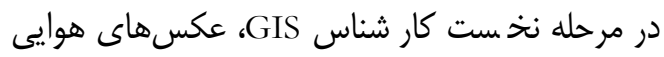

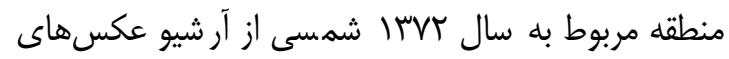

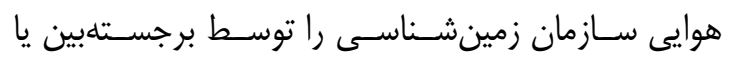

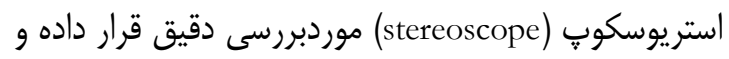

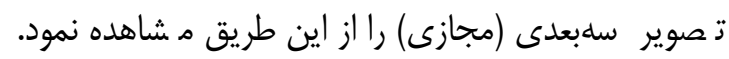

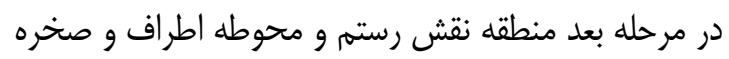

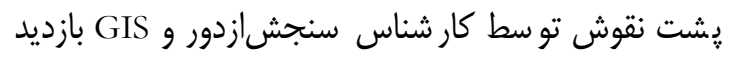

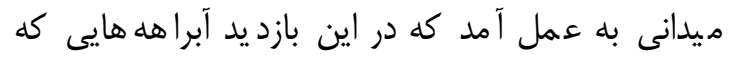

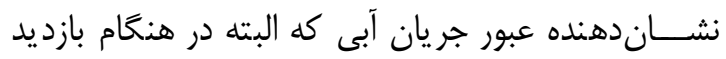

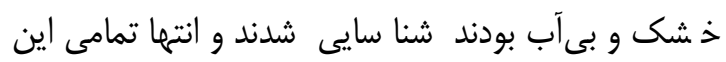
أبراهلها به صخره نقش رستم ختم مى بد (شكل ه ه ) [7].

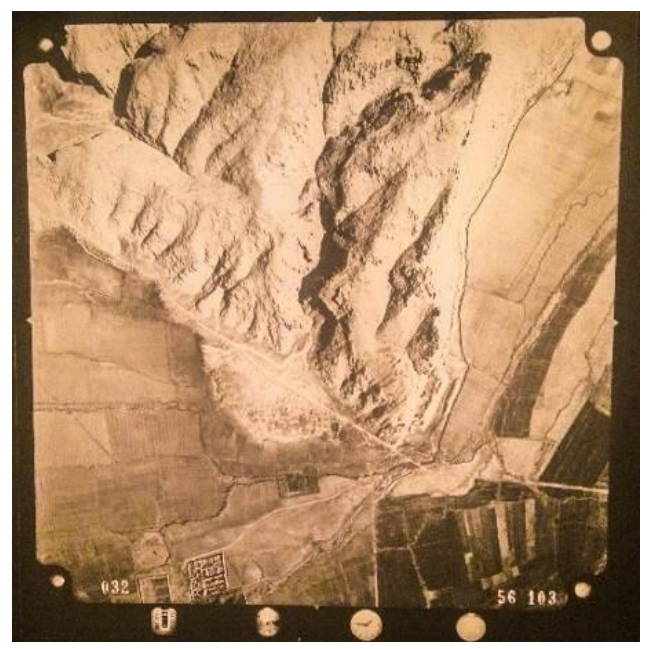

شكل ه: مشاهده مسير آبراهdهاى منتمى به نقش رستم عكس

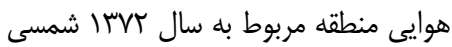

Fig. 5: Base runoff and alluvial soil image
سيستمهايى است كه توان تجزيهوتحليلهاى گسترده و اه كان برقرارى ارتباط بين مؤل فه هاى مختلف را باهم

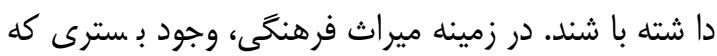

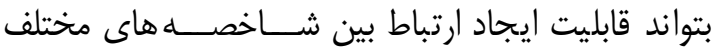

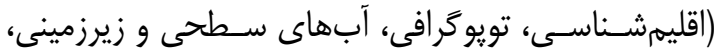

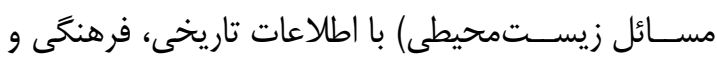

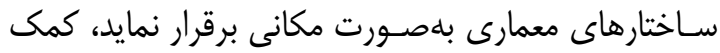
ويزهاى در جهت اخذ مناســبترين تصــميمات مديريتى

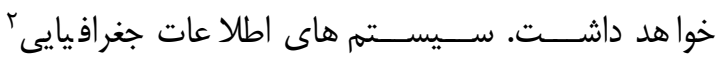
و ســــــ (Geographic Information System) (Remote Sensing)

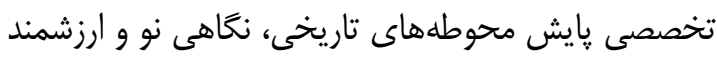
در مدير يت جامع ســايت ها و محوطه ها تاريخى ايجاد التهاد

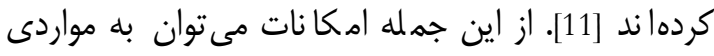

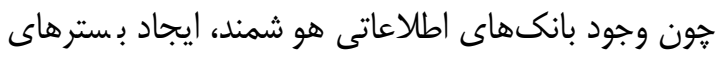
اطلاعات مكانى مشــترك از داده هاى مختلف، يردازش

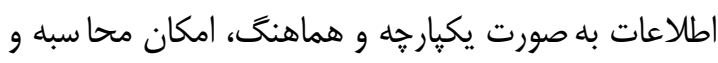

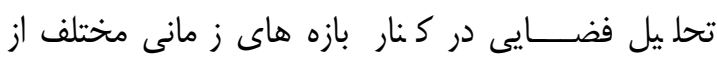

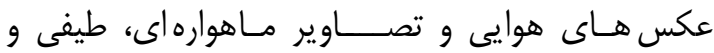

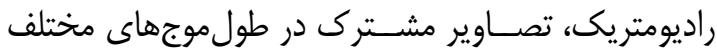
امواج الكترومغناطيس از محدوده مرئى تا امواج رادار، اشاره نمود. اين مطالعات بهَّونهاى اسـت كه مىتوان در كمترين

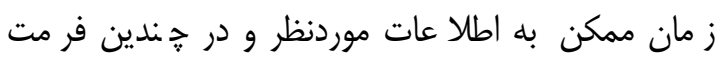
متفاوت مانند نقشههاى رقومى مكانى، تصاوير ماهوارهاى،

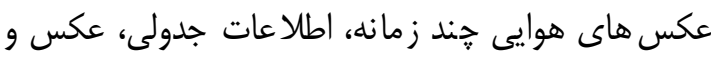
يَرَوَجَاهاى متنى، دستيافت [12,13]. ســـنشازدور مىتواند تغييرات دورهاى قيديده هاى سطح زمين را نشان دهد و در مواردى خون برر سى تغيير

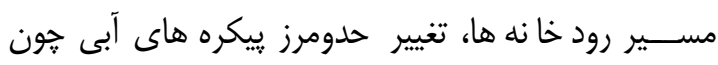

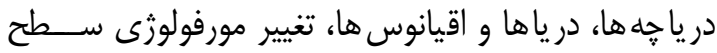

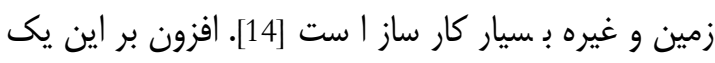

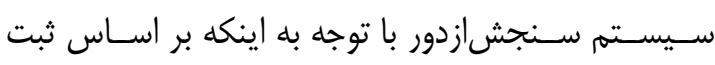
تغييرات و اختلاف هاى باز تابش الكترومغناطيســى از يديدههاى مختلف كار مى كند، مىتواند حدومرز بديدههاى

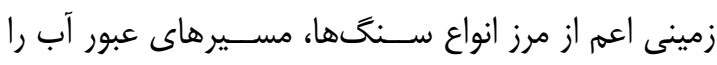

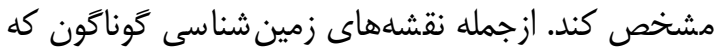

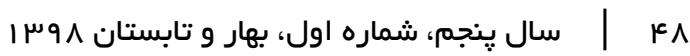


درواقع باسـتانشـناسـى فضـايى، روابط مكانى دادههاى

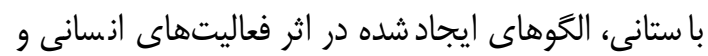

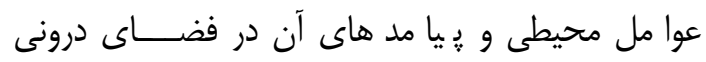
محوطههاى با ستانى و محيط اطراف آنها ران را مطالعه ميى

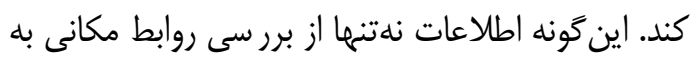

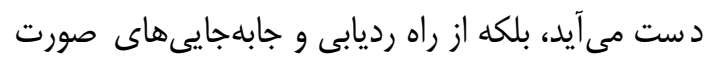

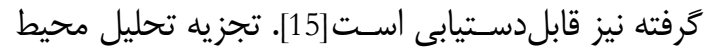

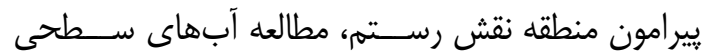

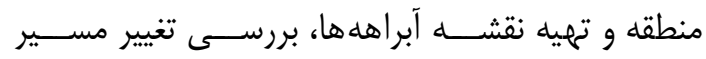

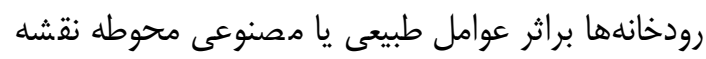

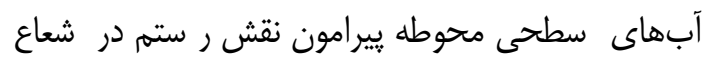

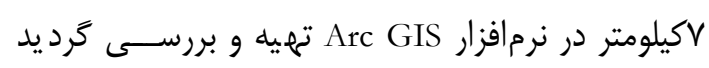
(شكل 9) كه بدون شك استفاده از اين فن نهتنها سرعت إنت انجام مطالعات را بيشتر مى كند، بلكه ازنظر دقت و هزينه و نيروى انسانى نيز بسيار باصرفهتر است.

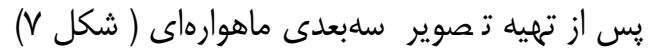

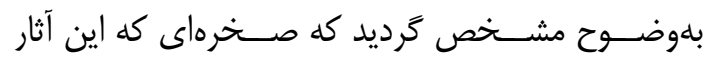

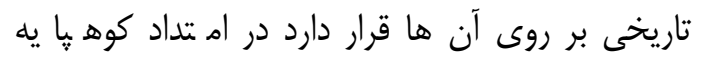
واقع شده و محل روان آبهاى جارى از كوه ستان دان دقيقاً

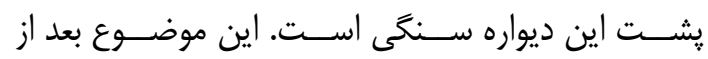

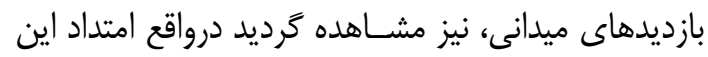

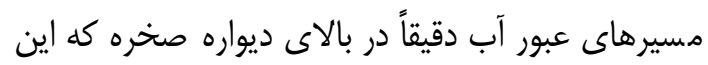

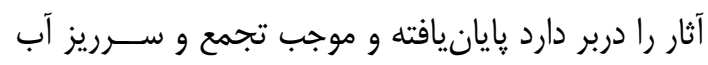

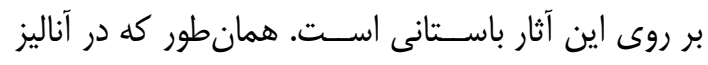
تصاوير مشخص گرديد در كوهيايه با يديده رود فصلى يانيا

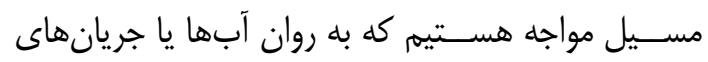

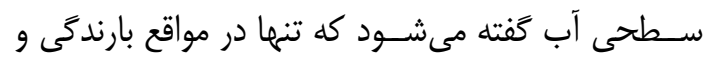

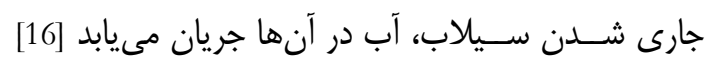

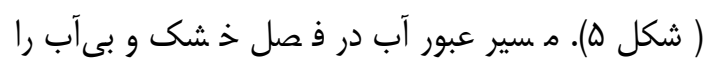

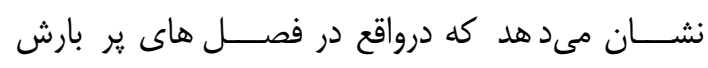

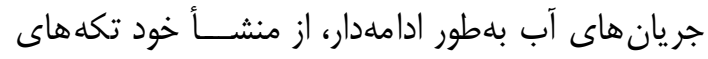

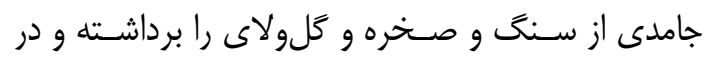

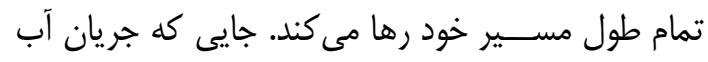

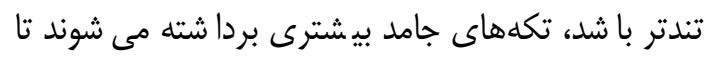

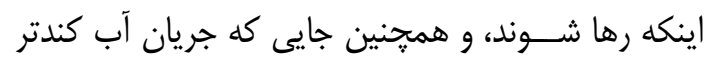

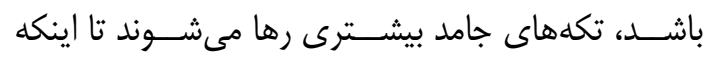
برداشته شوند. اخر در هنحام بارش، شدت بارئ بارندگى از

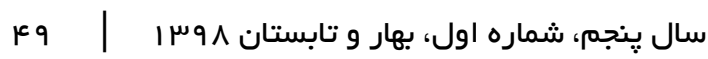

دادههاى جمع أورىشــــهـ در اين بررســى شــامل

اطلاعات محيطى و طيفى است. اطلاعات محيطى شامل دادل

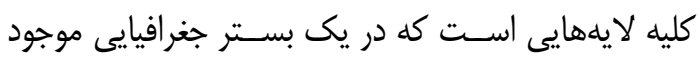
هســتند و شـامل لايههاى تويوكرافي، راهها، رودخانهها،

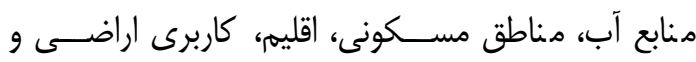

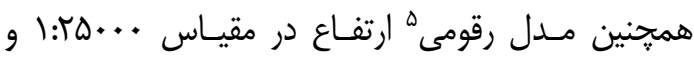

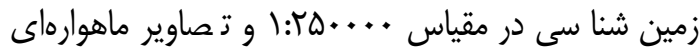

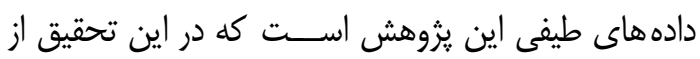

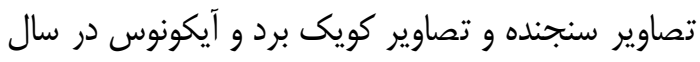

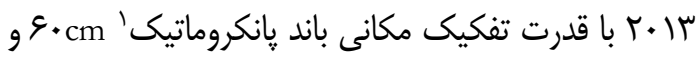

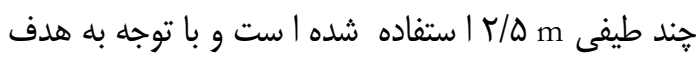

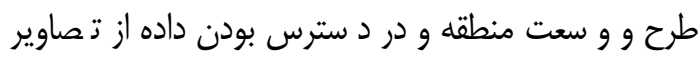

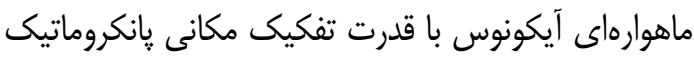

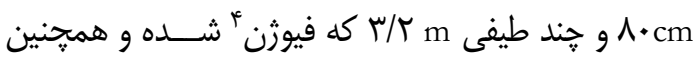

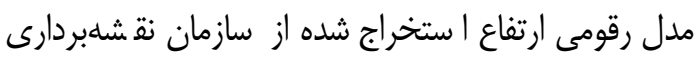

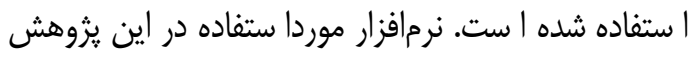

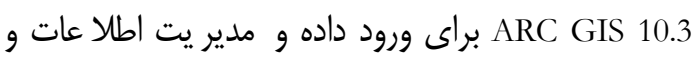
تحليل فضايى است. براى انجام اين مطالعات ابتدا اطلاعات زمينى شامل

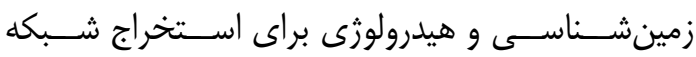

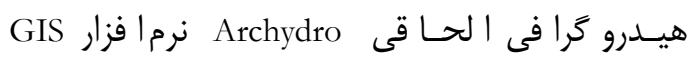

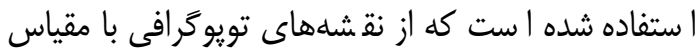

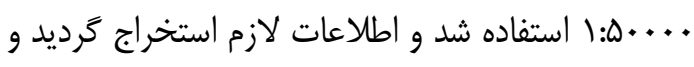

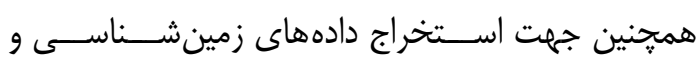

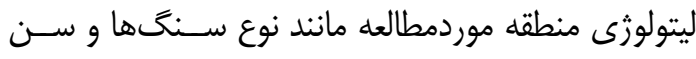

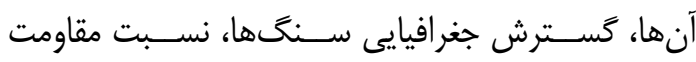

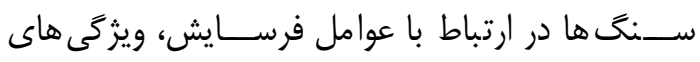

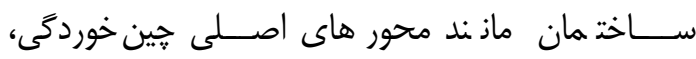

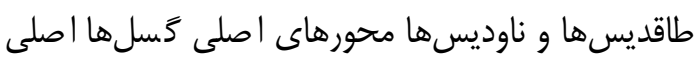

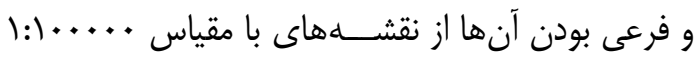

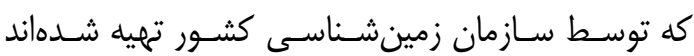

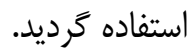

\section{f. (†. نتايج و يافتهها}

تجز يهوتحليل فضــايى در محوطه هاى باســانـانى در

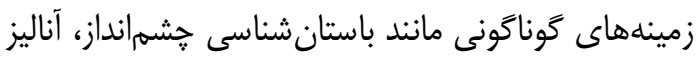
آمارى و باسـتانشـناسـى شــاختى اهميت زيادى دارد. 


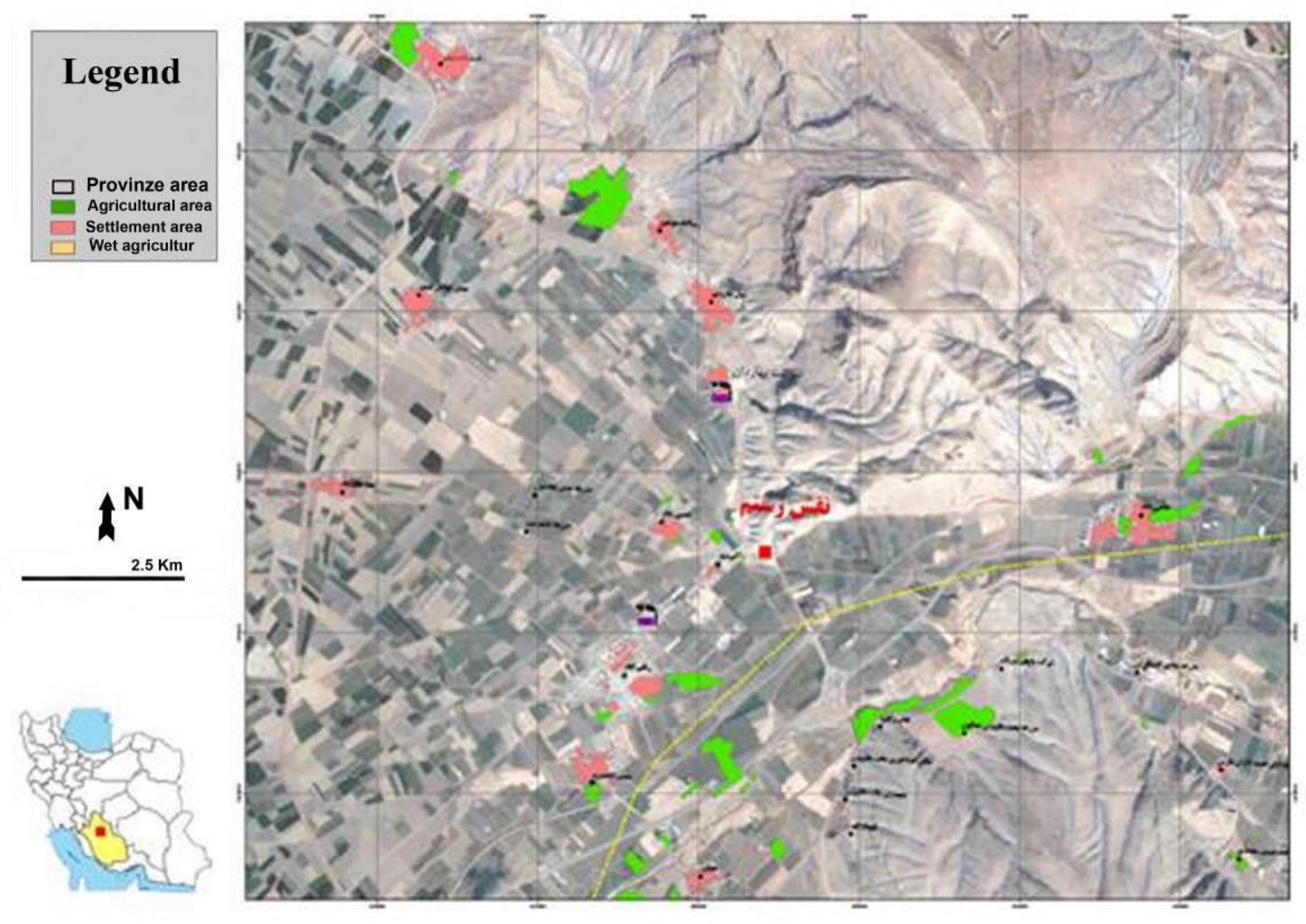

شكل צ: نقشه مسير عبور رودخانه از محوطه بيرامون نقش رستم

Fig. 6: Map of Naqsh-e Rostam and crossing the river

سنگ شاخصهاى زير به دست آمد. (جدول ()

\section{تعيين ويزَّى هاى ظاهرى سنَى (رنغَ، سختى، اثر اسيدكلريدريك):}

سختىى: سـادهترين روش سـنجش سـختى كانىهاى إس

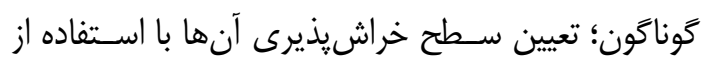

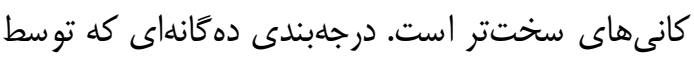

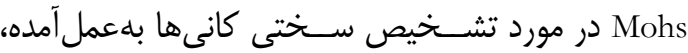

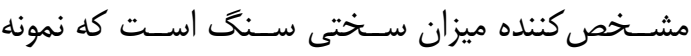
موردنظر با فولاد بلراحتى خرا شيده شد كه سختى سئ بين

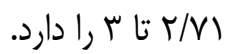

اثر اســيدكلر يدر يك رقيق: كربنات ها كه عمدتاً به صورت كربنات كل سيم هـ ستند يكى از كروههاى مهرم

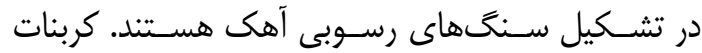
كلسـيم آماده تركيب با اسـيدها بوده و در حرارت كم به اله

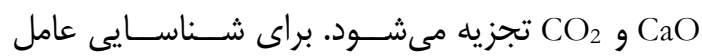
كربنات در سنگ مقدارى از نمونه را برداشته روى آن

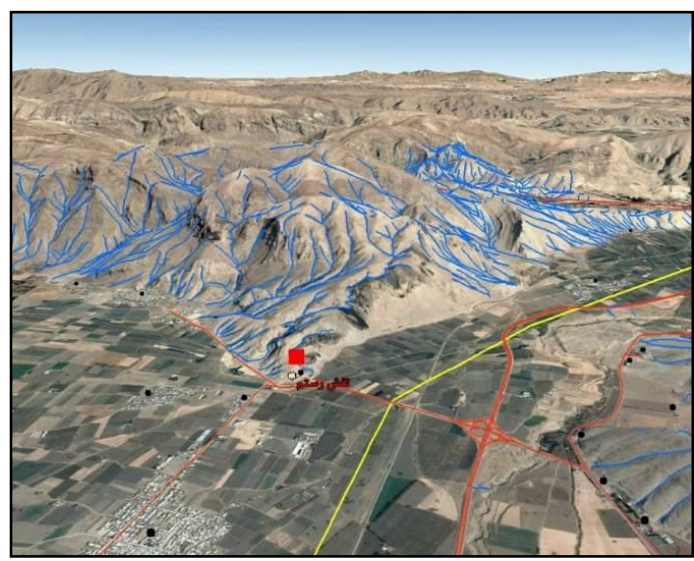

شكل V: تصوير ماهوارهاى سلبعدى آيكونوس از محوطه تاريخى نقش رسته إن

Fig. 7: Ikonos 3D satellite images of Naqsh-e Rostam

ظرفيت نفوذ آب به داخل زمين بيشـتر باشـد، بخشـى از

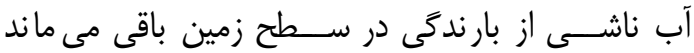
.[16,17]

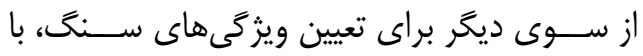

انجام آزمايش كانى شنا سى و تعيين ويزّى هاى ظاهرى 
جدول شماره (: ويزَى هاى نمونه سنگ از منطقه نقش رسته

Table 1. Appearance of Naqsh-e Rostam

\begin{tabular}{|c|c|c|c|c|}
\hline $\begin{array}{c}\text { اثر اسيدكلريدريك رقيق } \\
\text { Effect of du HCl }\end{array}$ & $\begin{array}{c}\text { سختى } \\
\text { Hardness }\end{array}$ & $\begin{array}{l}\text { رنغ سطح هوازده } \\
\text { Weathered color }\end{array}$ & $\begin{array}{l}\text { رنگ سطح تازه سنگ } \\
\text { Fresh surface color }\end{array}$ & $\begin{array}{c}\text { نمونه } \\
\text { Sample }\end{array}$ \\
\hline $\begin{array}{c}\text { مثبت } \\
\text { Positive }\end{array}$ & $\begin{array}{l}r \\
3\end{array}$ & $\begin{array}{c}\text { كرم با ركه قهوماى layers } \\
\text { Creamy with brown lay }\end{array}$ & خاكسترى شفاف & $\begin{array}{c}\text { نقش رستم } \\
\text { Naghshe-e Rostam }\end{array}$ \\
\hline
\end{tabular}

خواهند بود [16,18]. نتيجه آزكه با توجه به موقعيت جغرافيايى منطقه نقش رســتم و محل قرارگيرى اين آثار وقتى باران بر

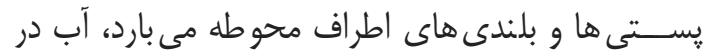
جهت شيب زمين حركت كرده و به صورت شبكاء از از

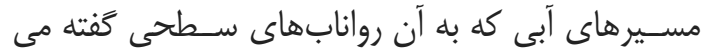
شود، و در يك مسير مشخص به به سمت اين آثار تاريخى حر كت كرده و درنهمايت در منطقهاى و در يك نقطه

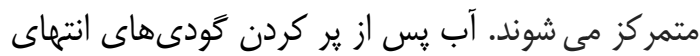

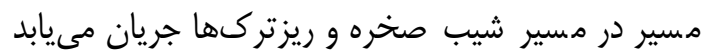

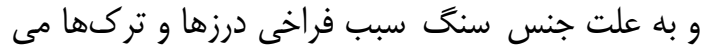

جدول شماره ז؟: آزمايشهاى فيزيكى نمونه سنگ از منطقه نقش رستم

Table 2. Mineralogical experiments of Naqsh-e Rostam

\begin{tabular}{|c|c|}
\hline 1580.7 & $\begin{array}{c}\text { وزن سنى اشباع (گرم) } \\
\text { Weight of saturated stone }\end{array}$ \\
\hline 1560.9 & $\begin{array}{c}\text { وزن سنگ خشك } \\
\text { Weight of dry stone }\end{array}$ \\
\hline 980.5 & $\begin{array}{c}\text { وزن سنگ غوطلور } \\
\text { Weight of immersion }\end{array}$ \\
\hline 600.2 & حجم كل سنى \\
\hline 19.84 & $\begin{array}{c}\text { حجم فضاى خالى } \\
\text { Volume of pores }\end{array}$ \\
\hline 580.4 & حجم حقيقى سنَى \\
\hline 2.634 & $\begin{array}{c}\text { دانسيته اشباع (g/Cm² } \\
\text { Densityy }\end{array}$ \\
\hline 2.6 & $\begin{array}{c}\text { دانسيته خشك }\left(\mathrm{g} / \mathrm{Cm}^{2}\right) \\
\text { Dry density }\end{array}$ \\
\hline 2.69 & $\begin{array}{c}\text { دانسيته حقيقى }\left(\mathrm{g} / \mathrm{Cm}^{2}\right) \\
\text { True density }\end{array}$ \\
\hline 1.271 & $\begin{array}{c}\text { جذب آب ج } \\
\text { Water absorption }\end{array}$ \\
\hline 3.306 & $\begin{array}{l}\text { \% تخلخل \% } \\
\text { Porosity }\end{array}$ \\
\hline
\end{tabular}

اسـيد كلريدريك رقيق اضـافه مى كنيه. در هنغام اضـافه

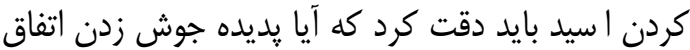
مىافتد كه در غير اين صورت نمك حاوى دايل ديد آنيون كربنات

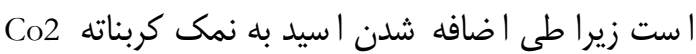
آزاد مىشود كه بلهورت جوشش نمود مىيابد. همجنين بعد از برداشــت نمونه با رطوبت محيطى

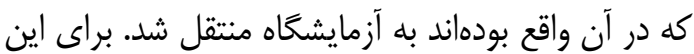
منظور از يار جههاى كتانى كه در يارافين ذوب خيســانده شده باشند جهت يوشاندن نمونه استفاده شد تا رسيدن

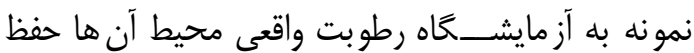
شود. يس از انتقال هر جه سريعتر به انجام آزمايشهاى

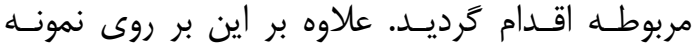
مشخصات آن قيد گرديد

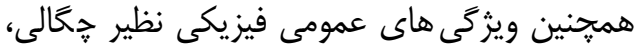

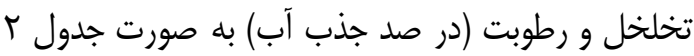

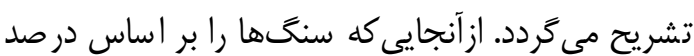
تخلخل ظاهرى به ه گروه از يك تا بيسـت تقسـيهم مى

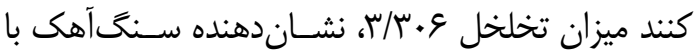
تخلخل متوســ اســت. درواقع به دليل درجه خلوص و تخلخل ثانو يه ســــــآ هك، در اثر تأثير نيرو هاى تكنونيكى ناشـى از حركت كوهزائى، اين ســـــها دهار شكستخى شده كه محل مناسبى براى نفوذ آب است. از

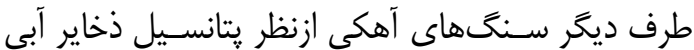
داراى ويثزى مخصــوص به خود اسـت، آب باران با حل

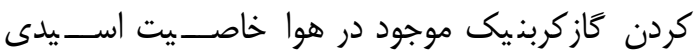
ييداكرده و درنتيجه نفوذ در داخل درز و شـــكافها مى تواند آن را در خود حل كرده و بهمرور موجب وســـيعتر

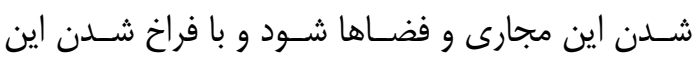
مجارى در طول سالها، حفرات كارستى بسيار بزرگى در

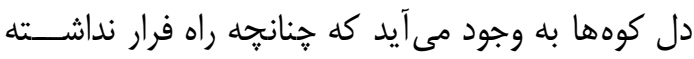

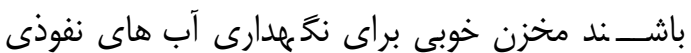


(Google earth) via Adecco محوطه نقش رسته در مطالعات ميدانى در اين تحقيق ما

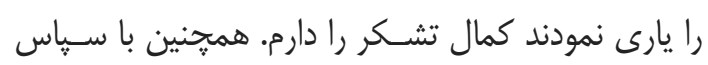

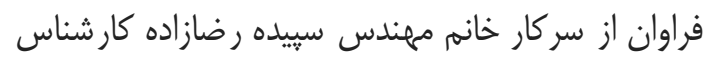

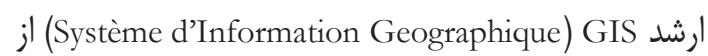
(UQAM) Université de Québec à Montréal دانشخاه كه در تحليل دادهها از راهنمايىهاى ارز شمند ايشان، در اين تحقيق استفاده شد.

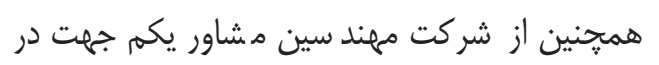
اختيار قرار دادن تصـاوير ماهوارهاى و دادههاى موردنياز

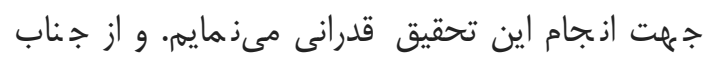

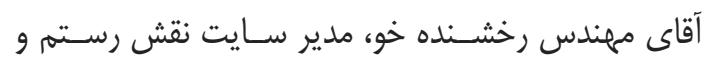

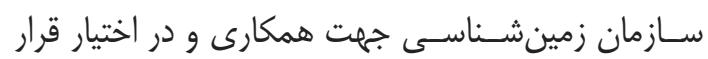

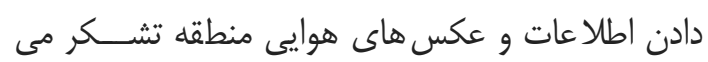

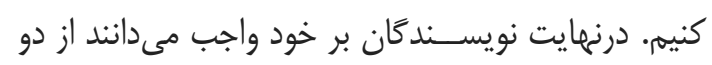
داور محترم اين مقاله كه بلهواسطه نقطه نظرات سات بازنده،

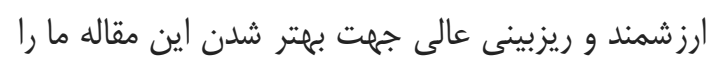
يارى نمودند، نهايت سياسخَزارى را داشته باشند.

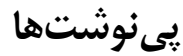

ا. تصـاوير يانكروماتيك (Panchromatic): اين تصـاوير يكى

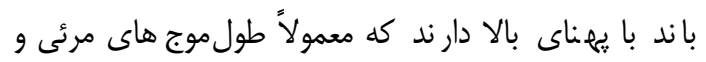

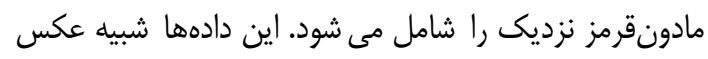

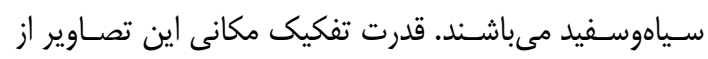
متوسط تا بسيار زياد است.

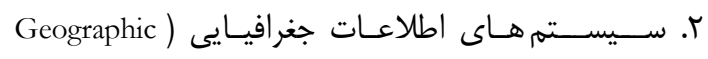
Information System واكاوى اطلاعات جغرافيايى بوده كه توانايى كردآورى، ذخيره، واكاوى و نمايش اطلاعات جغرافيايى را دارد.

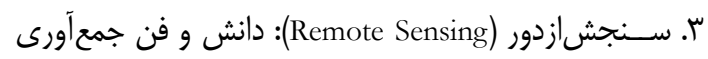
اطلاعات از اشياى روى سطح زمين، بدون حضور فيزيكى در

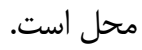
Fا فيوزن (Image Fusion) با اسـتفاده از اين تكنيك مي توان تصاوير داراى قدرت تفكيك مكانى و طيفى مختلف را در هم إنم

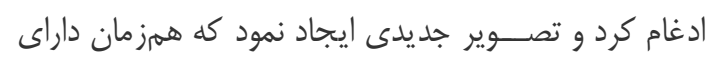

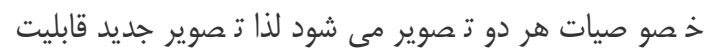

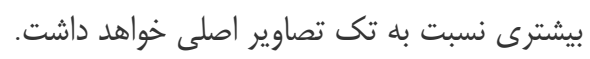

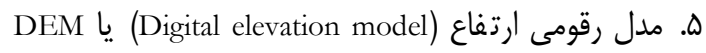

جهت شنا سايى دلايل به وجود آمدن تركهاى موجود بر

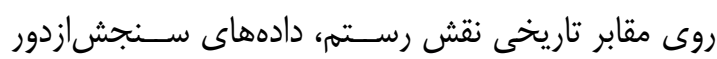

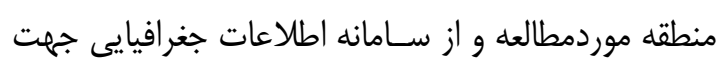

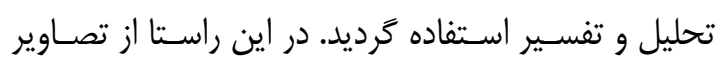

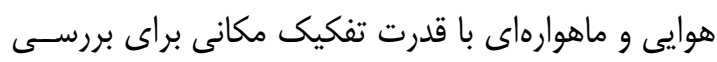

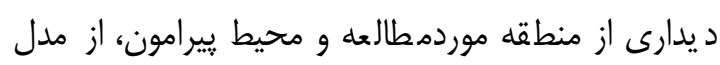

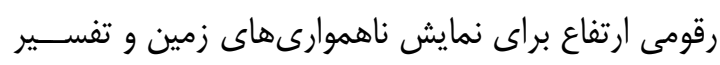

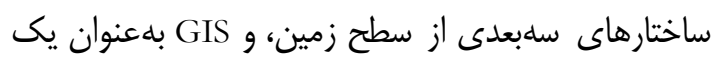

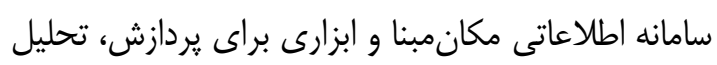

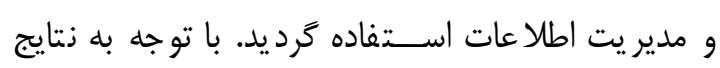

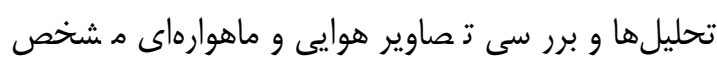

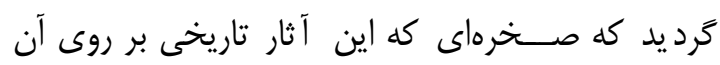

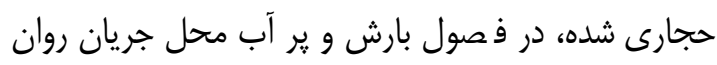

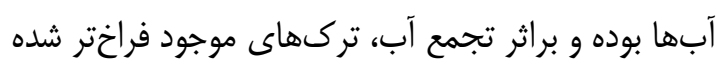

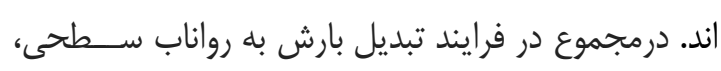

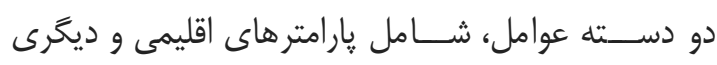

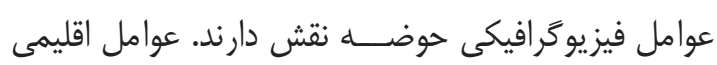

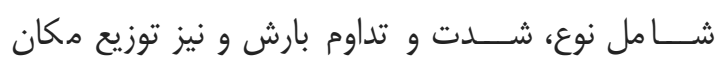

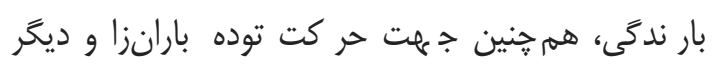

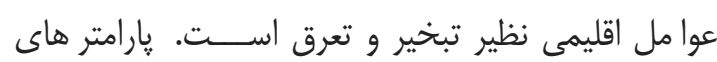

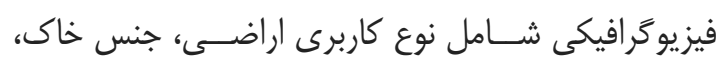

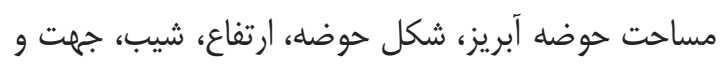

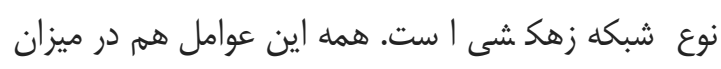

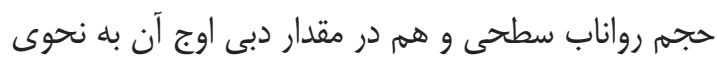

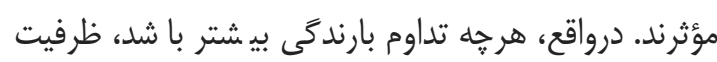

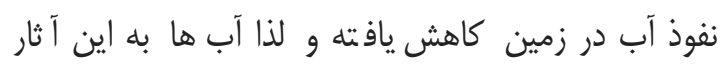

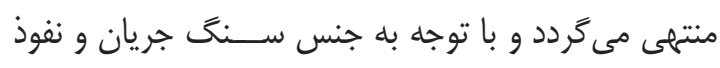

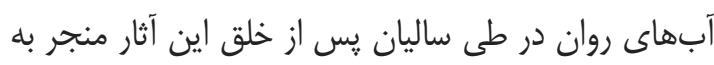
فراخى اين تركها بر روى سطح سنگ شده است. سياسگزارى

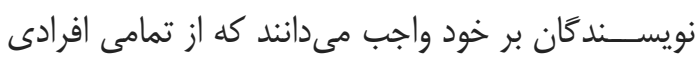

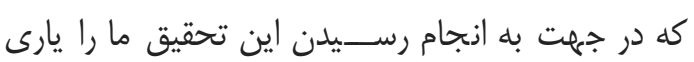

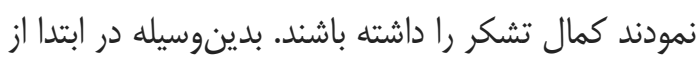

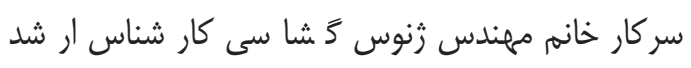

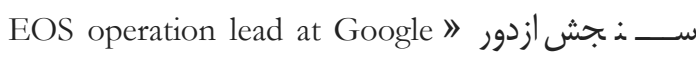

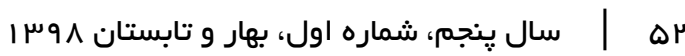


با استفاده از دادههاى ارتفاع از سطح دريا تهيه مىشود.

\section{References}

[1] Sami A. Report on Archeology. Tehran: 1972.

[2] Schmidt EF. Persepolis I. Structures, reliefs, inscriptions 1957.

[3] Shahbazi A. The Authoritative Guide to Naqsh-e Rostam. Tehran: Achaemenid Research Foundation; 1978. [in Persian]

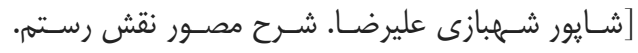
تهران: بنياد تحقيقات هخامنشى؛

[4] The World Heritage of Persepolis. Persepolis: Cultural Heritage, Handicrafts and Tourism Organization of Iran; 2004. [in Persian]

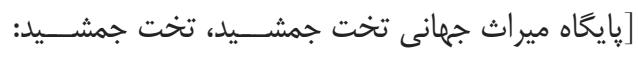

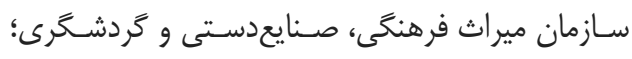

$[.1 \%$ «

[5] Geological Survey \& Mineral Explorations of Iran (GSI). Tehran: 2011. [in Persian]

] سازمان زمينشناسى و اكتشافات معدنى كشور. تهران:

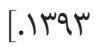

[6] Mostafavi M. Pars Climate, Historical Works and Fars Ancient Places. Tehran: University of Tehran Press; 1993. [in Persian]

[مصــــفوى محمدتقى. اقليم پارس و آثار تاريخى و

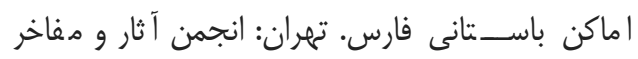

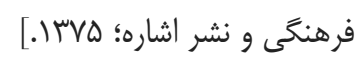

[7] National Geoscience Database of Iran 2008. [in Persian]

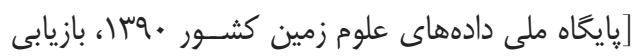
[/http://www.ngdir.ir jl

[8] Shirvani M. Pathology and Conservation of Historical Stone. Shiraz: Perspolice; 2005. [in Persian] .

آسيبشناسى و حفاظت از سنَّهاى تاريخى. شيراز:

$$
\text { تخت جمشيد؛ }
$$

[9] Moradi Ghiasabadi R, Farahani N. Persian Rock Relief. Tehran: Iranian research publications; 2010. [in Persian]

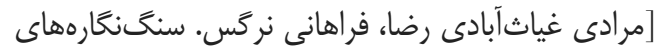

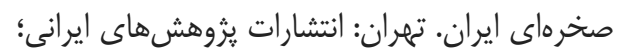

مدلى ديجيتال يا نمايشى سلبعدى از سطح زمين، ماه يا ديخر

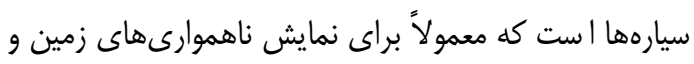

[..

[10] Qarib A. Knowing the rocks with a special look at the rocks of Iran. Tehran: Municipality Cultural and Cultural Organization; 1990. [in Persian]

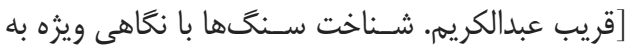

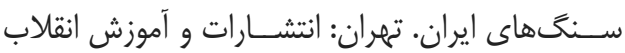

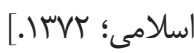

[11] Geographic Organization of the Armed Forces, Tehran, Geographic Organization of the Armed Forces Publications, 2002. [in Persian]

]ســازمان جغرافيايى نيروهاى مسـلح، اطلس راهنماى

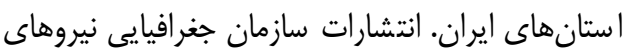

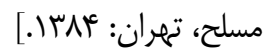

[12] Spreafico MC, Franci F, Bitelli G, Girelli VA, Landuzzi A, Lucente CC, et al. Remote sensing techniques in a multidisciplinary approach for the preservation of cultural heritage sites from natural hazard: The case of Valmarecchia Rock Slabs (RN, Italy). Eng. Geol. Soc. Territ. 8, Springer; 2015, p. 317-21.

[13] Youssef AM, Pradhan B, Al-Kathery M, Bathrellos GD, Skilodimou HD. Assessment of rockfall hazard at Al-Noor Mountain, Makkah city (Saudi Arabia) using spatio-temporal remote sensing data and field investigation. J African Earth Sci 2015;101:309-21.

[14] Oikonomidis D, Dimogianni S, Kazakis N, Voudouris K. A GIS/remote sensingbased methodology for groundwater potentiality assessment in Tirnavos area, Greece. J Hydrol 2015;525:197-208.

[15] Pickard R, Thyse M. Towards a common goal. Pick R(Ed), Manag Hist Centres, Spon Press Taylor Fr London, UK 2001:274-90.

[16] Refahi H. Water Erosion and Conservation. 2298th ed. Tehran: University of Tehran press; 2012. [in Persian]

]فاهى حسـينقلى. فرسـايش آبى و كتترل آن. تهران: 


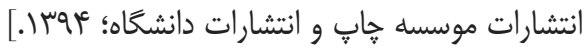

[17] Sedaghat M. Land and water resources.

Tehran: University of Payamenoor publications; 2010. [in Persian]

[صداقت محمود. زمين و منابع آب (آبهاى زيرزمينى).

تهران: انتشارات دانشكاه بيام نور؛ كوسו.]
[18] Movahed Danesh A. Iranian Surface Water Hydrology. Tehran: SAMT Publications; 2011. [in Persian]

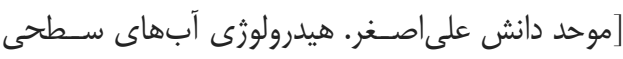

ايران. تهران: انتشارات سمت؛ سوحسا.] 